\title{
Using the Financial Analysis Approach to Forecast Industrial Production: A Guide from Jordan
}

\author{
H. Banikhalid ${ }^{1} \&$ S. Al-oshaibat ${ }^{1}$ \\ ${ }^{1}$ Department of Business Economic, Faculty of Business ,Tafila Technical University, Tafila, Jordan \\ Correspondence: Suleiman Daood Al-oshaibat, Department of Business Economic, Faculty of Business, Tafila \\ Technical University, Tafila, Jordan. E-mail: drslaimana@gmail.com
}

Received: February 24, 2020

Accepted: March 12, 2021

Online Published: April 10, 2021

doi:10.5539/ijbm.v16n5p91

URL: https://doi.org/10.5539/ijbm.v16n5p91

\begin{abstract}
This study aims to derive the function that can be used to predict the growth rate in the added value of industrial production in Jordan, depending on the financial ratios of industrial companies listed on the Amman Stock Exchange. To achieve the objectives of the study, the descriptive and analytical approach and multiple regression analysis were used using the SPSS program. The study population was represented by the public joint-stock companies listed on the Amman Stock Exchange in the industrial sector from 1994 to 2018. Results show that the financial ratios influencing the growth rate in industrial production value added the most (Industry $t+1$ ) are earnings per share (EPS), net profit margin (NPM), and return on equity (ROE). Moreover, the effect is non-linear expressed by a function that can be used to predict the industrial production in Jordan. The study recommends paying attention to the partial input to predict macroeconomic variables, especially with the development of systems for storing and processing big data, as this method provides appropriate and sufficient data to make accurate decisions and enhances the right track.
\end{abstract}

Keywords: financial analysis, growth in industrial production value added and financial ratios

\section{Introduction}

\subsection{Introduce the Problem}

Man has always sought to improve his life by customizing the surrounding environment to his advantage, thus, he strives to understand the laws that govern that particular environment. For instance, trying to modify the future by analyzing his/her own past. This general human behavior was not isolated from the economic aspects, through economic theorizing that worked on explaining economic behavior and phenomena, and derived economic laws, all with the aim of prediction: if the income of individuals increased, their consumption would increase, and consequently the total demand, and if interest rates decreased, demand would rise. In investment, if the money supply increases, prices will rise. One of the most prominent economic variables that require monitoring and follow-up is industrial production. If the industry is active, the efficiency of man's use of the components of his/her environment will increase and modify it for his/her wellbeing, which is the goal of the economy. Therefore, predicting this variable urges policy makers to shorten the time by amending everything that may reduce economic activity and support everything that is active.

\subsection{Problem of the Study}

If predicting the industrial output is crucial, then what are the tools that can be used to do so? Moreover, through logical sequential analysis, we realize that this total variable is merely a compilation of the partial activity of industrial establishments and is subject to their financial health, and thus the question arises about the feasibility of using financial analysis for industrial companies to forecast industrial production. The study questions can be summarized with the following questions:

1) Does a relationship exist between the profitability of Jordanian industrial companies and the growth rate in the added value of industrial production in Jordan?

2) Does a relationship exist between the solvency of Jordanian industrial companies and the growth rate in the added value of industrial production in Jordan?

3) Does a relationship exist between the market rates in Jordanian industrial companies and the growth rate in the added value of the industrial production in Jordan? 
4) What is the function that can be used to predict the growth rate in the added value of industrial production in Jordan?

\subsection{Importance of the Study}

The industrial output is one of the most important economic variables because it reflects an individual's ability to maximize his/her exploitation of the resources of his/her environment by converting raw materials into commodities more satisfying to human needs. This maximizes the efficiency of the use of relatively scarce resources and thus maximizes economic prosperity, which is the goal of an economic activity or science. Hence, forecasting macroeconomic variables, especially industrial production, is necessary for its reflection on the wellbeing of members of society, as the ability to predict with a high degree of accuracy on the basis of real-time data, such as financial ratios of companies operating in the sector enables proactive measures to be taken that address any problem and push the sector toward growth.

\subsection{Objectives of the Study}

1) Determine the relationship of the profitability of Jordanian industrial companies to the growth rate in the added value of the industrial production in Jordan.

2) Determine the relationship of the solvency of Jordanian industrial companies to the growth rate in the added value of the industrial production in Jordan.

3) Determine the relationship of market ratios in Jordanian industrial companies to the growth rate in the added value of industrial production in Jordan.

4) Derive the function that can be used to predict the growth rate in the added value of industrial production in Jordan.

\section{Previous Studies}

Looking at previous research contributions, we find that financial analysis as an input to forecast was employed partially, as a large group of researchers used financial analysis to predict the future financial conditions of companies, and we mention from that: the study (Jiang \& Lee, 2012), which confirmed the possibility of using financial ratios to predict basic returns For stocks, and a study (Yang \& Dimitrov, 2017) that found that using processed data is useful in predicting companies' default. Indeed, some studies have determined the accuracy of using financial analysis in forecasting, such as the study (Correa-Mejía \& Lopera-Castaño, 2020), which concluded that the financial ratio analysis could be used to predict the failure of companies for a period of three years with an accuracy rate of $70 \%$, this percentage increased to $80 \%$ According to the results of the study (Alireza \& others, 2021).also, (Slimi, 2012) studied the effect of business cycles in certain countries in the Middle East and North Africa on the profitability of banks. The study concluded that the effect of recession is not certain on the profitability of banks and it varies by country and a study of (Ibrahim, et al., 2017) discussed several macro and partial indicators including financial indicators for banks - that can be used as an early system to monitor financial crises before they occur. To predict them, the researchers also urge future studies to try to prevent crises and a study of (Jameel, 2003) monitored many macro indicators, in addition to several partial indicators for banks related to liquidity and capital adequacy, which preceded the occurrence of financial crises in numerous countries.

With regard to forecasting industrial production, as mentioned previously, we did not find a study that dealt with the financial analysis to predict this aggregate variable, and among the variables that were used to predict industrial production, the business confidence index according to a study (Bodo \& others, 2000), and electricity consumption according to a study (Marchetti \& Parigi, 2000), macro-financial indicators according to a study (Forni, and others, 2003), industrial confidence index according to a study (Cizmesija \& Bahovec, 2009), and money supply indicators according to a study (Gupta \& Sako, 2013).

However, we conclude from previous studies that the possibility of predicting industrial production by monitoring the factors that inhibit and motivate it, and on the other hand that the use of financial analysis as a tool to predict the financial conditions of companies has proven its worth and it is not denied that it is used to predict the macro variables of the economy, and this is what this study did, This particular point is the distinguishing mark between these studies and previous studies. By reviewing previous studies, we found that studies that dealt with the subject in the Jordanian economy remain scarce. Therefore, researchers hope that this study will be supplemental to the series of research within the case of the Jordanian economy. 


\section{Theoretical Framework}

\subsection{The Concept of Financial Analysis}

Financial analysis is an organized treatment of financial data that aims to explain the financial position of an enterprise and showing weaknesses and strengths in the financial body of the facility to make a decision related to the facility (Alneame, 2014). This decision can range from the company's management's decision to expand or reduce business, or an outside investor's decision to buy the company's shares or refrain from doing so, or a lender's decision to lend the company or not (George et al., 2003; Sarngadharan, 2011).

The necessity of financial analysis comes from the importance of investment and financial decisions that determine the future of individuals, institutions and society. If these decisions are based on a sound and accurate analysis, those decisions are directed toward the goal directly - whether this goal is a manager who wants to maximize the wealth of the company's owners, or an investor who intends to achieve a rewarding return, or a creditor hoping for his/her money to return.

\subsection{Financial Analysis for Jordanian Industrial Companies}

Financial analysis has numerous methods. This study chose the method of financial analysis by ratios, as follows:

1- Profitability ratios that show the company's ability to generate profits. This study used the net profit margin, return on assets (ROA), and return on equity ROE.

2- Solvency ratios, which determine the company's ability to pay its obligations, whether short or long term and each of the following has been used: the debt ratio, the ownership percentage, and the trading ratio.

3- Market ratios, which are used to evaluate the company's share price in the financial market. This study used EPS, market value to return, and dividends to market value.

These percentages were specifically chosen to be published regularly by the Amman Stock Exchange for most of the years of the study, and in case they were not published, the researchers calculated them on the basis of the data published by Amman Stock Exchange, see Table (1), and we extracted from these data the following results:

Market ratios indicate a gradual increase in the multiples of profitability in the Jordanian industrial companies during the study periods until it reached a maximum of 130 times in 2004, and this indicates the disconnect between the market share price and EPS and an imbalance in the efficiency of the financial market. However, things have changed since 2015 as the earnings repeaters began to decline with an increase in EPS.

Profitability ratios refer to three phases (see Figure 1): The first phase from 1994 to 2004 and is characterized by low rates of profitability, and as of 2005 the profitability tended to rise and reached a peak in 2008, when the return on equity reached $25 \%$.

Table 1. Selected financial ratios for the industrial sector in Jordan (The percentages are calculated based on the aggregate data of the industrial companies listed on the Amman Stock Exchange)

\begin{tabular}{|c|c|c|c|c|c|c|c|c|c|}
\hline Years & EPS & $\mathrm{P} / \mathrm{E}$ & Dividend Yield Ratio \% & NPM \% & ROA \% & ROE \% & Debit Ratio \% & Equity Ratio \% & Current Ratio \\
\hline 1994 & 0.12 & 27.34 & 2.42 & 5.45 & 3.69 & 7.04 & 47.64 & 52.36 & 1.62 \\
\hline 1995 & 0.11 & 20.08 & 2.78 & 5.48 & 3.80 & 7.33 & 48.24 & 51.83 & 1.45 \\
\hline 1996 & 0.11 & 20.08 & 2.78 & 5.48 & 3.80 & 7.33 & 48.53 & 51.83 & 1.34 \\
\hline \multicolumn{10}{|l|}{1997} \\
\hline 1998 & 0.10 & 15.37 & 4.79 & 4.48 & 2.84 & 5.72 & 50.37 & 49.63 & 1.51 \\
\hline 1999 & 0.05 & 36.76 & 3.93 & 2.24 & 1.53 & 2.93 & 47.72 & 52.28 & 1.68 \\
\hline 2000 & 0.02 & 94.55 & 3.62 & 0.94 & 0.65 & 1.25 & 48.07 & 52.36 & 1.54 \\
\hline 2001 & 0.02 & 110.70 & 3.65 & 0.91 & 0.65 & 1.18 & 45.83 & 55.17 & 1.57 \\
\hline 2002 & 0.02 & 123.42 & 3.34 & 0.80 & 0.63 & 1.15 & 45.65 & 55.24 & 1.80 \\
\hline 2003 & 0.02 & 163.68 & 2.70 & 0.66 & 0.59 & 1.01 & 42.23 & 59.04 & 2.07 \\
\hline 2004 & 0.03 & 130.19 & 3.12 & 1.12 & 1.06 & 1.84 & 42.75 & 57.25 & 2.09 \\
\hline 2005 & 0.40 & 7.21 & 11.39 & 12.44 & 1.08 & 12.18 & 40.31 & 59.69 & 2.19 \\
\hline 2006 & 0.27 & 8.28 & 9.26 & 9.83 & 1.35 & 9.66 & 37.90 & 62.10 & 1.82 \\
\hline 2007 & 0.54 & 4.63 & 11.14 & 16.50 & 1.39 & 16.77 & 37.78 & 62.22 & 1.80 \\
\hline
\end{tabular}




\begin{tabular}{lllllllllll}
\hline 2008 & 0.58 & 10.40 & 2.61 & 19.42 & 15.03 & 24.74 & 37.92 & 62.08 & 1.75 \\
2009 & 0.26 & 22.65 & 2.43 & 12.81 & 6.85 & 10.69 & 35.09 & 64.91 & 1.78 \\
2010 & 0.28 & 22.79 & 2.36 & 12.10 & 7.45 & 10.94 & 31.80 & 68.20 & 1.91 \\
2011 & 0.46 & 13.43 & 5.66 & 16.28 & 10.92 & 15.88 & 30.88 & 69.12 & 2.10 & 2.16 \\
2012 & 0.37 & 18.05 & 4.47 & 13.65 & 8.77 & 12.32 & 28.58 & 71.42 & 1.93 \\
2013 & 0.18 & 26.31 & 4.15 & 7.59 & 4.30 & 6.21 & 31.23 & 68.77 & 1.85 \\
2014 & 0.20 & 19.88 & 4.60 & 7.55 & 4.77 & 6.89 & 31.54 & 68.46 & 1.93 \\
2015 & 0.22 & 17.51 & 4.37 & 9.09 & 5.40 & 7.71 & 30.78 & 69.22 & 69.19 & 1.85 \\
2016 & 0.03 & 118.50 & 4.39 & 1.70 & 0.85 & 1.15 & 30.81 & 69.75 & 1.62 \\
2017 & 0.07 & 59.83 & 3.19 & 3.08 & 1.62 & 2.39 & 35.25 & 64.75 & 60.44 & 1.65 \\
\hline 2018 & 0.19 & 18.34 & 4.20 & 8.21 & 4.31 & 7.09 & 39.56 & & \\
\hline
\end{tabular}

Source: Amman Stock Exchange (https://www.ase.com.jo/ar), and some were calculated by researchers depending on the financial data published by the stock exchange. The researchers were unable to calculate the percentages for the year 1997 due to lack of data. The general trend of the solvency of the Jordanian industrial companies improved, as the debt ratio in 1998 was approximately $50 \%$, and decreased to $30 \%$ in 2016.

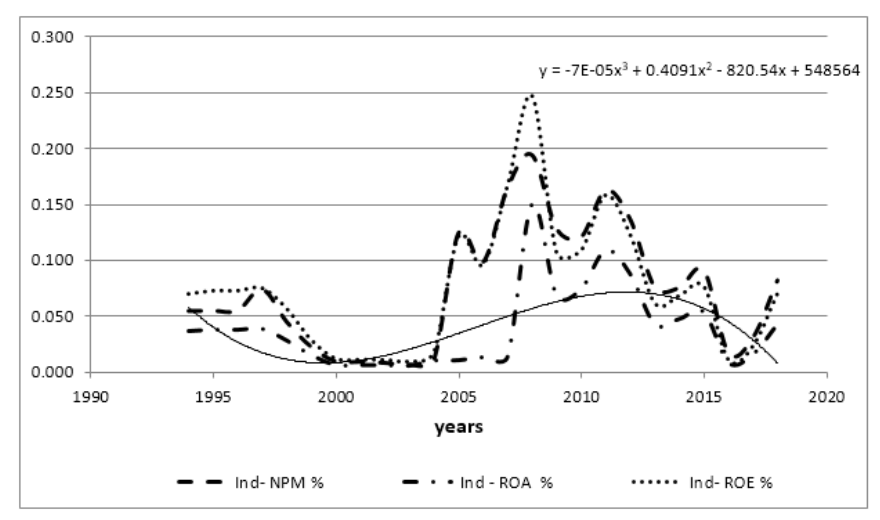

Figure 1. Evolution of the profitability of Jordanian industrial companies

Liquidity was characterized by relative stability, as the current ratio fluctuated between 1.5 to 2 times during most of the school years.

3. Jordanian industrial production: Although the services and tourism sectors are the most influential sectors in the Jordanian economy, the industrial sector is considered an influential and substantial sector. Based on the 2016 statistics, its contribution to Jordan's GDP reached 24\%, and it also contributed to employment at roughly $15 \%$ of the total workforce. The most prominent point regarding this sector is that it is responsible for $85 \%$ of Jordanian exports (http://www.mit.gov.jo/Ar/List/.page2).

Considering Table 2, which represents the growth in the added value of the industrial sector, as the added value, according to what the World Bank has defined: "is the net product of the sector after adding all the outputs and subtracting the intermediate inputs (https://datacatalog.worldbank.org/public-licenses\#cc-by) the table exhibits that the sector achieved positive growth in most of the years of study, and a negative growth transpired only for two years: 1996 and 2009. Generally, the average growth in the added value of industrial production in Jordan during the years of study was about $4.9 \%$, which is a good rate. We found that the contribution of the industrial sector to GDP increased from 18\% at the end of the 1980s to 24\% in 2016 (http://www.mit.gov.jo/Ar/List/). 
Table 2. Growth of the value added of Jordanian industrial production

\begin{tabular}{llll}
\hline Years & Industry, value added (annual \% growth) & Years & Industry, value added (annual \% growth) \\
\hline 1994 & 0.124 & 2007 & 0.095 \\
1995 & 0.040 & 2008 & 0.078 \\
1996 & -0.044 & 2009 & -0.013 \\
1997 & 0.073 & 2010 & 0.019 \\
1998 & 0.035 & 2011 & 0.042 \\
1999 & 0.065 & 2012 & 0.008 \\
2000 & 0.042 & 2013 & 0.016 \\
2001 & 0.082 & 2014 & 0.039 \\
2002 & 0.151 & 2015 & 0.028 \\
2003 & 0.019 & 2016 & 0.009 \\
2004 & 0.126 & 2017 & 0.018 \\
2005 & 0.065 & 2018 & 0.013 \\
2006 & 0.101 & & \\
\hline
\end{tabular}

Source: World Bank national accounts data, and OECD National Accounts data files: https://datacatalog.worldbank.org/public-licenses\#cc-by

However, we must distinguish between two different phases: the first phase from 1997 to 2008, when the sector achieved high growth averaging about $8 \%$, whereas in the period that followed, the growth rates decreased, as the average growth for the period from 2009 to 2018 was approximately 2\%, which is a major shift, see Figure 2.

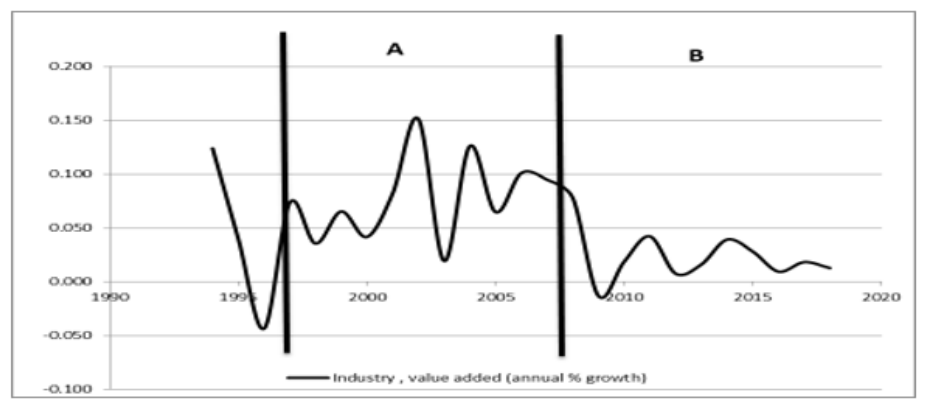

Figure 2. Evolution of the growth of value added of Jordanian industrial production

\section{Methodology}

A. Theoretical aspect: In preparing the theoretical framework and clarifying the concepts, the two researchers relied on the descriptive approach on the basis of collecting information from books and research, whether Arabic or English for the clarity and brevity of the research message.

B. Practical aspect: the two researchers conducted an applied study on the industrial sector in Jordan.

C. Data collection method:

(Raw) is one of its features on the Internet, as the financial ratios were obtained from the website of the Amman Stock Exchange (https://www.ase.com.jo/ar).

In the event that some financial ratios were not disclosed in some years, the two researchers calculated the missing percentages by also relying on the financial data published on the Amman Stock Exchange website. As for the historical data for the annual growth rate in the added value of the Jordanian industrial sector, this study obtained such data from the World Bank statistics published on the website (https://databank.worldbank.org)

D. Data analysis method: This study used a set of statistical methods in analyzing data and Measuring relationships using Microsoft Excel and SPSS program. The two researchers used Descriptive statistics tools for the primary analysis of the data (mean, lowest value, highest value). To test the relationships, this study tested multiple linear regression, correlation coefficient, and Determination coefficient, and used the T-test for statistical significance. 


\section{Hypotheses}

To answer the study's questions and achieve its objectives, the two researchers tested four hypotheses to demonstrate the possibility of using the financial analysis approach in forecasting industrial production in Jordan. The main study, the hypotheses are:

A. Hypothesis 1: A positive and strong relationship exists between the profitability of the Jordanian industrial companies and the growth rate in the added value of industrial production in Jordan in the following year.

B. Hypothesis 2: A positive and strong relationship exists between the solvency of the Jordanian industrial companies and the growth rate in the added value of the industrial production in Jordan in the following year.

C. Hypothesis 3: A positive and strong relationship exists between market ratios and the growth rate in the added value of industrial production in Jordan in the following year.

D. Hypothesis 4: Industrial production can be predicted by knowing the financial ratios of industrial companies.

\section{Variables}

A. Measuring the dependent variable: The dependent variable is the percentage of growth in the industrial value added of industrial production in Jordan (Table 2) (2010). Value added is the net product of the sector after adding all outputs and subtracting intermediate inputs.

B. Measurement of independent variables: Independent variables is a set of the aggregate financial ratios for the Jordanian industrial sector. This study selected these ratios specifically due to their regular publication during study periods, except for the years (1997 to 2004), as the ratios were calculated by researchers, and the ratios were not calculated for the year 1997. Given the lack of data, this study handled the command by linear interpolation through SPSS. This study adopted the following financial ratios as independent variables:

First: The profitability ratios group: This group is used to determine the company's ability to generate profits, and this group includes:

1) NPM: It shows the percentage of adding each dinar of sales to net profits and is

2) calculated by dividing the net profit after sales tax.

3) ROA: It shows the amount of net profits that the company generates for every dinar invested in the assets and is calculated by dividing the net profits after taxes on the total assets.

4) ROE It shows the amount of net profits generated against each dinar in equity and is calculated by dividing the net profits after taxes on shareholders' equity.

Second: The market ratios group: This group is used to estimate the market value of the share by linking it to the basic data of the company.

1) EPS: It shows the share of the ordinary share of the net profits and is calculated by dividing the net profits after taxes by the number of shares subscribed.

2) Market value to return (P/E): It shows the investors' willingness to pay for every unit of profit the share generates and is calculated by dividing the market value of the shares subscribed by the net profits after taxes.

3) Dividend yield ratio: It shows the dividends that the investor acquires for every dinar he/she pays as a price for the share and is calculated by dividing the cash dividends on the market value of the subscribed shares.

Third: Solvency ratio group: This group is used to determine the company's ability to pay its obligations. This group includes:

1) Debit ratio: It shows the company's ability to pay its obligations and is calculated by dividing current liabilities by assets.

2) Equity ratio: It shows the company's ability to pay its obligations and is calculated by dividing shareholders' equity by the assets.

3) Current ratio: It shows the company's ability to pay its short-term obligations, and is calculated by dividing current assets by current liabilities.

4) Study population and sample: The study is a case study on the Jordanian economy. With regard to the financial ratios used, they are aggregate financial ratios for all industrial companies listed on the Amman Stock Exchange.

5) Hypotheses tests of the study: 


\section{A. First hypothesis test}

A positive and strong relationship exists between the profitability of the Jordanian industrial companies and the growth rate in the added value of industrial production in Jordan in the following year.

To test Hypothesis 1, this study used several statistical tests as follows:

First: Looking first at Figure (3), which links the ROA and the growth rate in the added value of industrial production, it shows that this relationship has gone through two stages: Stage (A) represents the period from 1994 to 2009 and the relationship between the two variables has disappeared, and it is estimated that the correlation between them is close to zero. Stage (B) represents the period 2010 to 2018 . The fact is The strength of the correlation between the two variables and the relationship between them is estimated as strong and positive. Thus, confirming the linear relationship between the two variables is difficult.

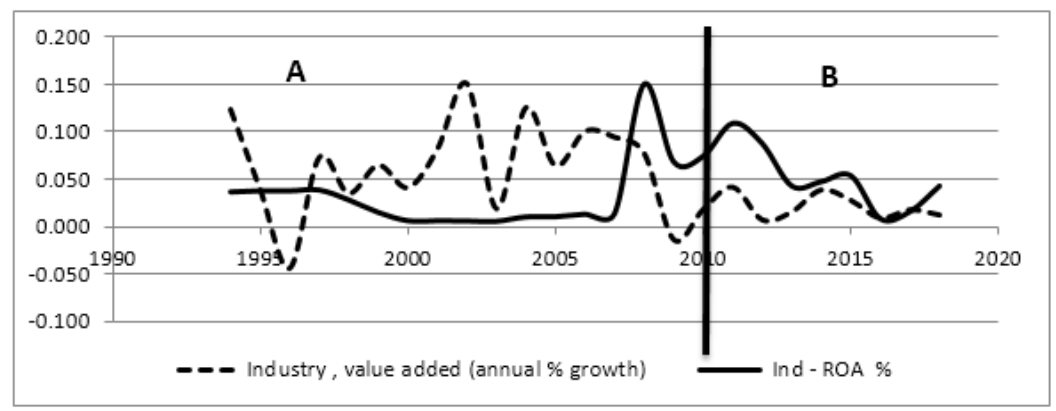

Figure 3. The relationship between the profitability of industrial companies and industrial production in Jordan

Second: We used Pearson's correlation coefficient to determine the direction and strength of the relationship between the two variables and used the SPSS program with the results presented in Table (3). The table presents that the relationship is weak to non-existent between profitability ratios and the growth rate in the added value of industrial production, and this result is not statistically significant at a $95 \%$ confidence level, and thus rejecting Hypothesis 1.

Table 3. The correlation between profitability and industrial production ratios

\begin{tabular}{llc}
\hline Variable 1 & Variable 2 & R \\
\hline Industry, value added (annual \% growth) & Ind- NPM \% & -0.078 \\
Industry, value added (annual \% growth) & Ind - ROA \% & -0.712 \\
Industry, value added (annual \% growth) & Ind- ROE \% & 0.299 \\
\hline
\end{tabular}

Source: prepared by researchers via SPSS.

\section{B. Second hypothesis test}

A positive and strong relationship exists between the solvency of the Jordanian industrial companies and the growth rate in the added value of the industrial production in Jordan in the following year. To test Hypothesis 2 , this study used several statistical tests as follows: First: Looking primarily at Figure (4), which links the annual growth in the ownership ratio (equity ratio) and the growth rate in the added value of industrial production, we find that a strong correlation exists between the two variables when large changes in the solvency of industrial companies are present, whether it may be the significant rise in solvency or the great decline. Moreover, the relationship is negative when the solvency tends to decline, which soon turns to positive when it improves significantly, and the relationship is closer to a non-linear quadratic relationship. 


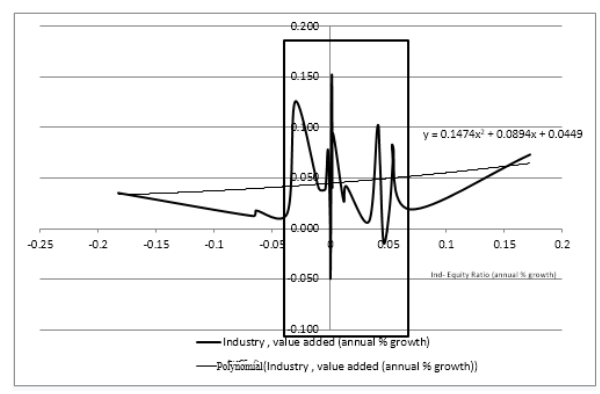

Figure 4. The relationship between the solvency of industrial companies and industrial production in Jordan

Source: the figure prepared by researchers using Excel based on the Amman Stock Exchange data regarding ownership percentage, and World Bank data regarding industrial production.

Second: This study used Pearson's correlation coefficient to determine the direction and strength of the relationship between the two variables, and used the SPSS program with the results presented in Table (4). The table reveals that the relationship is weak between the solvency ratios and the growth rate in the added value of industrial production. Ultimately, this result is not relevant. The statistical significance is at a $95 \%$ confidence level, and thus rejecting Hypothesis 2.

Table 4. The correlation between solvency ratios and industrial production

\begin{tabular}{llr}
\hline Variable 1 & Variable 2 & R \\
\hline Industry , value added (annual \% growth) & Ind - Debit Ratio \% & 0.315 \\
Industry, value added (annual \% growth) & Ind- Equity Ratio \% & -0.314 \\
Industry, value added (annual \% growth) & Ind - Current Ratio & 0.127 \\
\hline
\end{tabular}

Source: prepared by researchers via SPSS.

\section{Third hypothesis test}

A positive and strong relationship exists between market ratios and the growth rate in the added value of industrial production in Jordan in the following year.

To test this hypothesis, this study performed several statistical tests as follows:

First: Looking first at Figure (5) the dividends distributed to the market value (dividend yield ratio) and the growth rate in the added value of industrial production, we find that this relationship has gone through two phases: Phase (A) represents the period from 1994 to 2003, and the relationship between the two variables has ceased to exist. We estimated that the correlation between them is close to zero, Phase (B), and represents the period 2004 to 2018. The strength of the correlation between the two variables is apparent, and the relationship between them is estimated as strong and positive. Thus, confirming the linear relationship between the two variables is difficult.

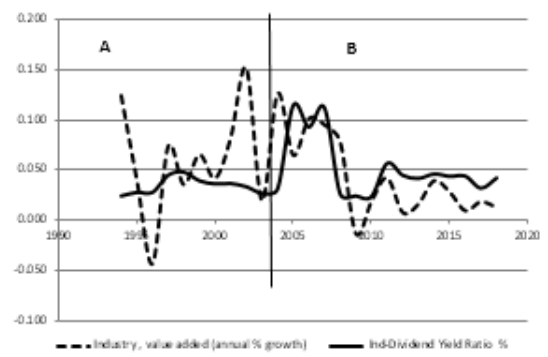

Figure 5. The relationship between market percentages and industrial production in Jordan

Source: the figure prepared by researchers using Excel based on the Amman Stock Exchange data regarding ownership percentage, and World Bank data regarding industrial production. 
Second: This study used Pearson's correlation coefficient to determine the direction and strength of the relationship between the two variables and used the SPSS program with the results exhibited in Table (5). The table shows that the relationship is non-existent to weak between market ratios and the growth rate in the added value of industrial production, and this result is not statistically significant at a $95 \%$ confidence level, and thus rejecting Hypothesis 3.

Table 5. the correlation between market ratios and industrial production

\begin{tabular}{llll}
\hline variable 1 & Variable 2 & $\mathrm{R}$ & Sig. \\
\hline Industry , value added (annual \% growth) & Ind-EPS & 0.010 & 0.963 \\
Industry, value added (annual \% growth) & Ind-P/E & 0.217 & 0.298 \\
Industry, value added (annual \% growth) & Ind-Dividend Yield Ratio \% & 0.240 & 0.248 \\
\hline
\end{tabular}

Source: prepared by researchers via SPSS.

D. Fourth hypothesis test:

Industrial production can be predicted by knowing the financial ratios of industrial companies.

To test this hypothesis, the researchers took the following steps:

A. Determining the shape of the function that links the dependent variable to each of the independent variables separately, by extracting R2 using the SPSS statistical software package, and the result is as follows:

Table 6. The percentage of determination (R2) for each independent variable separately

\begin{tabular}{llllllllll}
\hline Function & EPS & P/E & Div. Yield & NPM & ROA & ROE & Debit \% & Equity\% & CR \\
\hline Linear & 0.172 & 0.172 & 0.037 & 0.037 & 0.353 & 0.353 & 0.004 & 0.005 & 0.026 \\
Logarithmic & 0.071 & 0.071 & 0.063 & 0.063 & 0.146 & 0.146 & 0.007 & 0.004 & 0.024 \\
Inverse & 0.028 & 0.028 & 0.088 & 0.088 & 0.057 & 0.057 & 0.009 & 0.003 & 0.022 \\
Quadratic & 0.374 & 0.374 & 0.106 & 0.106 & 0.688 & 0.688 & 0.046 & 0.042 & 0.032 \\
Cubic & 0.600 & 0.600 & 0.116 & 0.116 & 0.872 & 0.872 & 0.046 & 0.044 & 0.031 \\
Compound & 0.031 & 0.031 & 0.002 & 0.002 & 0.031 & 0.031 & 0.184 & 0.186 & 0.103 \\
Power & 0.002 & 0.002 & 0.022 & 0.022 & 0.001 & 0.001 & 0.199 & 0.176 & 0.108 \\
S & 0.001 & 0.001 & 0.053 & 0.053 & 0.001 & 0.001 & 0.212 & 0.166 & 0.111 \\
Growth & 0.031 & 0.031 & 0.002 & 0.002 & 0.031 & 0.031 & 0.184 & 0.186 & 0.103 \\
Exponential & 0.031 & 0.031 & 0.002 & 0.002 & 0.031 & 0.031 & 0.184 & 0.186 & 0.103 \\
\hline
\end{tabular}

Source: Prepared by researchers using the SPSS program.

The table reveals that making a comparison between the different forms of functions using the coefficient of determination R2 is possible, As the greater the determination coefficient R2 indicates that the function shape is better to indicate the responsibility of the independent variable for the changes occurring in the dependent variable, the researchers adopted the following functions:

Table 7. The appropriate functions to determine how the dependent variable is affected by the independent variables

\begin{tabular}{lllllllllll}
\hline Independent. variable & EPS & P/E & Div. Yield & NPM & ROA & ROE & Debit $\%$ & Equity $\%$ & CR \\
\hline Function Type & Cubic & Cubic & Cubic & Cubic & Cubic & Cubic & S & Exponential & S \\
\hline
\end{tabular}

Source: Prepared by researchers using the SPSS program.

B. Building the standard model: The model comprises a single nonlinear function, as follows:

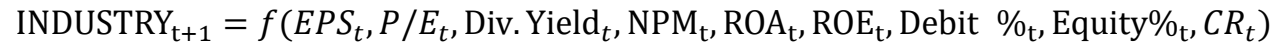

$$
\begin{aligned}
& \text { INDUSTRY }_{\mathrm{t}+1}=\alpha+\beta_{1} E P S_{t}+\beta_{2} E P S_{t}{ }^{2}+\beta_{3} E P S_{t}{ }^{3}+\beta_{1} P / E_{t}+\beta_{2} P / E_{t}{ }^{2}+\beta_{3} P / E_{t}{ }^{3}+\beta_{1} \text { Div. Yield } t \\
& +\beta_{2} \text { Div. Yield }{ }_{t}^{2}+\beta_{3} \text { Div. Yield }{ }^{3}+\beta_{1} \mathrm{NPM}_{t}+\beta_{2} \mathrm{NPM}_{t}{ }^{2}+\beta_{3} \mathrm{NPM}_{t}{ }^{3}+\beta_{1} \mathrm{ROA}_{t}+\beta_{2} \mathrm{ROA}_{t}{ }^{2} \\
& +\beta_{3} \mathrm{ROA}_{t}{ }^{3}+\beta_{1} \mathrm{ROE}_{t}+\beta_{2} \mathrm{ROE}_{t}{ }^{2}+\beta_{3} \mathrm{ROE}_{t}{ }^{3}+\mathrm{e}^{\left(\beta+\frac{\beta}{\text { Debit } \%}\right)}+\beta^{\beta \mathrm{Equity}_{\mathrm{t}}}+\mathrm{e}^{\left(\beta+\frac{\beta}{C R_{t}}\right)}
\end{aligned}
$$


C. Estimating the parameters of the standard model: By using SPSS, the new variables (EPSt2, EPSt3, P/Et2, ...) were calculated, then using multiple linear regression analysis according to the backward elimination method, which is based on inserting all the variables in the model and then excluding the independent variables. The least influenced by the dependent variable and keeping only the independent variables with the largest correlation and statistically acceptable, and the kept variables in the model are as follows (see Appendix 2):

Table 8. Estimation of model parameters

\begin{tabular}{lll}
\hline Independent var. & $\boldsymbol{\beta}$ & $\mathbf{A}$ \\
\hline EPS & -5.009 & 0.077 \\
ROE & 16.358 & 0.034 \\
$\mathrm{NPM}^{3}$ & -522.618 & 0.038 \\
$\mathrm{ROE}^{3}$ & 544.442 & 0.000 \\
\hline
\end{tabular}

Table 5 reveals that these remaining variables explain $90.5 \%$ of the changes in the dependent variable, which is a very large percentage and supports the model. These results can be statistically adopted with confidence greater than $95 \%$.

Table 9. The statistical significance of the model

\begin{tabular}{lll}
\hline $\mathrm{R}^{2}$ & $\mathrm{~F}$ & Sig. \\
\hline 0.905 & 45.255 & 0.000 \\
\hline
\end{tabular}

D. Estimated function: Based on previous results, the following function can be adopted to predict the growth rate in the added value of industrial production:

$$
\text { Industry_ }(\mathrm{t}+1)=-0.041-5.009 \text { EPS } \rrbracket-t-522.618[\mathrm{NPM}-\mathrm{t}]^{\wedge} 3+16.358 \mathrm{ROE}-\mathrm{t}+544.442[\mathrm{ROE}-\mathrm{t}]^{\wedge} 3
$$

By testing the correlation between the true and the estimated, we obtain the results in Table 10, which indicate high reliability by adopting this function, as the correlation rate reached $95.1 \%$ with a confidence degree of approximately $99 \%$.

Table 10. The correlation between real and estimated values through the derivative function

\begin{tabular}{|c|c|c|c|}
\hline & & $\begin{array}{l}\text { Industry (including construction), value added } \\
\text { (annual \% growth) after one year }\end{array}$ & Eindustryt 1 \\
\hline \multirow{2}{*}{\multicolumn{2}{|c|}{$\begin{array}{l}\text { Industry (including construction), Pearson Correlation } \\
\text { value added (annual } \% \text { growth) after Sig. ( } 2 \text {-tailed) }\end{array}$}} & 1 & $.951^{* *}$ \\
\hline & & & .000 \\
\hline \multirow[t]{2}{*}{ one year } & $\mathrm{N}$ & 24 & 24 \\
\hline & Pearson Correlation & $.951^{* *}$ & 1 \\
\hline \multirow[t]{2}{*}{ Eindustryt1 } & Sig. (2-tailed) & .000 & \\
\hline & $\mathrm{N}$ & 24 & 24 \\
\hline
\end{tabular}

**. Correlation is significant at the 0.01 level (2-tailed).

\section{Results and Recommendations}

\subsection{Results}

1. Jordanian industrial companies have endured multiple profitability during the study periods, and this indicates the disconnection of the relationship between the market share price and the EPS and an imbalance in the efficiency of the financial market.

2. Jordanian industrial companies suffered from the instability of profit rates, and the rates of profitability were low during the period prior to 2005.

3. The general trend of the solvency of the Jordanian industrial companies improved, and liquidity was 
characterized by relative stability.

4. Although the Jordanian industrial sector achieved positive growth in most of the years of schooling, it witnessed a deceleration after 2009, as the average growth for the period from 2009 to 2018 was approximately $2 \%$.

5. Although a positive correlation exists between profitability ratios and the growth rate in the added value of industrial production after 2009, the statistical tests for the entire study period indicate the lack of relationship between the two variables, and this result is not statistically significant at a $95 \%$ confidence level.

6. Although a strong correlation exists between the solvency ratios and the growth rate in the added value of industrial production in the years that witnessed a major change in solvency. The statistical tests for the entire study period, which included slight changes in the solvency, indicate a lack of relationship between the two variables, and this result is not statistically significant at a $95 \%$ confidence level.

7. Although a positive correlation exists between market ratios and the growth rate in the added value of industrial production after 2003, statistical tests for the entire study period indicate the absence of a relationship between the two variables, and this result is not statistically significant at a $95 \%$ confidence level.

8 . The most influential financial ratios by the growth percentage in industrial production value added (Industry- $t+$ 1) are EPS, NPM, and ROE, and the effect is non-linear expressed by the following function, which is: they can be used to predict industrial production in Jordan:

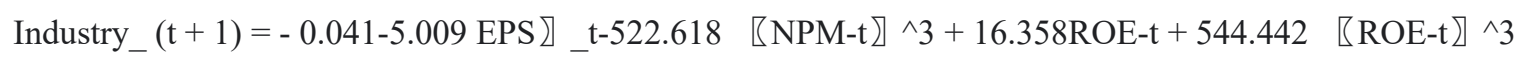

\subsection{Recommendations}

The study recommends researchers and economic policy leaders to pay attention to the partial approach in predicting macroeconomic variables, especially with the development of systems for storing and processing big data, as this method provides appropriate and sufficient data for accurate decision making and promotes the sound path.

\section{Limitations of the Study}

- Objective Limits: The study dealt with the relationship of the outputs of the financial analysis and the financial ratios specifically without taking other factors affecting the industrial output. This study used financial ratios that were regularly published by the Amman Stock Exchange throughout the study period.

- Time limits: The study covers the period from 1994 to 2018.

- Spatial boundaries: The study was applied to the industrial sector in the Hashemite Kingdom of Jordan.

\section{References}

Alireza, F., Parviz, M., \& Mina, S. (2012). Evaluation of the Financial Ratio Capability to Predict the Financial Crisis of Companies. IUP Journal of Behavioral Finance, 57-69.

Al-Nuaimi, A. (2014). Financial Management (5th ed.). Dar Al-Masirah, Amman.

Belqla, B., Hariri, A., \& Mattay, A. (2017). The Effectiveness of Early Warning Systems in Preventing Financial Crises. Journal of Research in Accounting and Finance, 2(4), 32-48.

Bodo, G., Golinelli, R., \& Parigi, G. (2000). Forecasting industrial production in the euro area. Empirical economics, 25(4), 541-561.

Cizmesija, M., \& Bahovec, V. (2009). Forecasting the Direction of Changes in Croatia's Industrial Production with IC and Crolei. Investigation Operational, 30(2), 140-148.

Correa-Mejía, D. A., \& Lopera-Castaño, M. (2020). Financial ratios as a powerful instrument to predict insolvency; a study using boosting algorithms in Colombian firms. Estudios Gerenciales, 36(155), 229-238. https://doi.org/10.18046/j.estger.2020.155.3588

Forni, M., Hallin, M., Lippi, M., \& Reichlin, L. (2003). Do financial variables help forecasting inflation and real activity in the euro area? Journal of Monetary Economics, 50(6), 1243-1255

George, T. F., \& Lydia, L. F. S. (2003). Essentials of Financial Analysis.

Gupta, R., Ye, Y., \& Sako, C. M. (2013). Financial variables and the out-of-sample forecast ability of the growth rate of indian industrial production. Technological \& Economic Development of Economy, 19, S83-S99. https://doi.org/10.3846/20294913.2013.879544

Industrial Policy. (2016). Ministry of Industry and Trade, Industrial Policy Division (p. 2). 
Jamil, H. A. (2003). Financial Crises: Their Concept, Indicators and Predictability. Damascus University Journal, 19(1), 279-299.

Jiang, X., \& Lee, B. S. (2012). Do Decomposed Financial Ratios Predict Stock Returns and Fundamentals Better? Financial Review, 47(3), 531-564. https://doi.org/10.1111/j.1540-6288.2012.00339.x

Marchetti, D. J., \& Parigi, G. (2000). Energy Consumption, Survey Data and the Prediction of Industrial $\begin{array}{lllll}\text { Production in Italy. Journal of } & 419 .\end{array}$ https://doi.org/10.1002/1099-131X(200009)19:5<419::AID-FOR749>3.0.CO;2-J

Sarngadharan, M. (2011). Financial Analysis for Management Decisions. PHI Learning Pvt. Ltd.,

Yang, X., \& Dimitrov, S. (2017). Data envelopment analysis may obfuscate corporate financial data: using support vector machine and data envelopment analysis to predict corporate failure for nonmanufacturing firm. INFOR, 55(4), 295-311. https://doi.org/10.1080/03155986.2017.1282290

\section{Copyrights}

Copyright for this article is retained by the author(s), with first publication rights granted to the journal.

This is an open-access article distributed under the terms and conditions of the Creative Commons Attribution license (http://creativecommons.org/licenses/by/4.0/). 